INTERNATIONAL JOURNAL OF MULTIDISCIPLINARY RESEARCH AND ANALYSis

ISSN(print): 2643-9840, ISSN(online): 2643-9875

Volume 04 Issue 12 December 2021

DOI: 10.47191/ijmra/v4-i12-12, Impact Factor: 6.072

Page No.- 1847-1855

\title{
Social Exchange between Candidate Head of Village with Voters in Tuban Regency, East Java, Indonesia
}

\author{
Ciptono ${ }^{1}$, Ishomuddin ${ }^{2}$, Rinekso Kartono ${ }^{3}$, Jabal Tarik Ibrahim ${ }^{4}$ \\ ${ }^{1,3}$ Doctoral of Sociology, University of Muhammadiyah, Malang \\ ${ }^{2}$ Professor of Sociology, University of Muhammadiyah, Malang \\ ${ }^{4}$ Professor of Agriculture, University of Muhammadiyah, Malang
}

\author{
Corresponding Author: Ishomuddin \\ Professor, University of Muhammadiyah, Malang
}

\begin{abstract}
This article is a summary of research on social exchange between Candidate Village Heads and voters in Tuban Regency, East Java. Village democracy is considered a "genuine" democracy that can be used as an orientation in the development of modern democracy at the national level, with characteristics such as deliberation, village meetings and village head elections by the people in the village, from the candidates they propose themselves. Thus, the village has been officially recognized as a democratic entity that has autonomous power in administering its government independently in accordance with the wishes and needs formulated by its own citizens. Based on the description of the research background above, the problems that become the focus of this research are formulated as follows: (1) What is the type of social exchange that occurs between candidates and voters in the 2019 Sumberarum Village Head Election? (2) What elements form the social exchange between candidates and voters in the 2019 Sumberarum Village Head Election? (3) How did the candidate take advantage of the social exchange arena to win the 2019 Sumberaum Village Head Election? (4) What are the patterns of social exchange that occur between candidates and voters in the 2019 Sumberarum Village Head Election?
\end{abstract}

KEYWORDS: Social Exchange, Villagers, Voters, Tuban District

\section{INTRODUCTION}

The election of village heads since Law Number 32 of 2004 concerning Regional Government (hereinafter referred to as the Regional Government Law) has been relatively free, fair and autonomous from higher levels and influential elites. Elections are conducted by the BPD and are held by the village itself and take place every six years. Villagers are free to choose a candidate for village head and this is a clear departure from the closely monitored village head elections of the New Order. At that time strict controls were exercised when village head candidates had to get the blessing or approval of the district government to be able to run or to be later inaugurated, regardless of the election results.

As a result, the political arena in the village is open to more qualified and responsive leaders. Democratization has helped reduce the space for dynastic leadership. For example, in one village in Jambi, the new village head was the first not to come from a ruling clan. Villagers and non-dominant groups are described as "arrogant people" (arrogant people), showing their hatred. In another village in Jambi, the son of a migrant from Bengkulu who married a woman in that village was elected twice, in 2003 and 2009. One Central Java village head came from a small hamlet and marginalized religious group, and in another village the son of the incumbent, whose father and brother are former village heads, were not elected because the villagers wanted change (Antlöv, Wetterberg and Dharmawan, 2016).

According to Widjaja (2008), the village in a political perspective is a democratic society, a society that is based on the sovereignty of the people. Village democracy is what is considered to be "original" democracy that can be used as an orientation in the development of modern democracy at the national level, with characteristics such as deliberation, village meetings and village head elections by the people in the village, from the candidates they propose themselves. Thus, the village has been officially 


\section{Social Exchange between Candidate Head of Village with Voters in Tuban Regency, East Java, Indonesia}

recognized as a democratic entity that has autonomous power in administering its government independently in accordance with the wishes and needs formulated by its own citizens.

The model of presidential election (Presidential election), legislative election (legislative election) and direct post-conflict local election with the principle of 'one person, one vote' (one man one vote), has actually been implemented for a long time at the election of the village head. Democratization at the village level increasingly appears to be the object of regional autonomy regulation by the Central Government, when the Regional Government Law is issued. The Regional Government Law contributes to significant and fundamental changes in the administration of local government, even at the village government level. In 2014 the Law of the Republic of Indonesia Number 6 of 2014 concerning Villages (hereinafter referred to as the Village Law) was passed. The Village Law mandates the Village Head and the Village Consultative Body (BPD) to carry out democratization at the village level. BPD is an institution that embodies democracy in the administration of village government. The BPD can be considered as the village's 'parliament' whose function is to establish Village Regulations (Perdes) with the Village Head (Village Head), accommodate and channel the aspirations of the community. In reality, democracy in the village does not merely apply the principles of true democracy. The choice of the Village Head, the election of BPD members and deliberation at the village level are more transactional. Social exchange during the election of the village head, the election of BPD members, the election of village officials, and decision making at the village level cannot be avoided from the practice of social exchange.

Democratization at the village level has significance for two reasons: First, in the village arena, democracy is an effort to redefine the relationship between village communities and elites or Village Government administrators (Village Heads and their apparatus and BPD). Through democracy, the village also applies the general definition of power, namely power comes from and is in the hands of the people. This kind of understanding places the villagers in a bargaining position when choosing the village head. This means that villagers as voters can choose the candidate they support in accordance with the rewards received from the candidate. This kind of position, in social exchange, can be formulated that "candidates give money, basic necessities, promises, opportunities, opportunities, to their voters". Or vice versa, "voters cast their votes for the candidate they choose". Based on this definition, it means that the community or villagers are the true owners of the power (the village), not the elite or the organizers of the village government. The Village Government Organizer is only the executor of the power of the village people, not the owner of power or even the owner of the village. Second, related to the progress marked by the Village Law in looking at the position of the village. One of the most important parts of the Village Law is the State's acknowledgment of the right to village origins (the principle of recognition) and the determination of local-scale authority and local decision-making for the benefit of the village community (the principle of subsidiarity). With these two principles, the village has enormous authority to take care of itself (Amanulloh, 2015: 10-11).

Antlov (2003), '...in the past the village was the object of centralization, depoliticization, co-optation, intervention, and instructions from above. Now the village is an arena of democracy, autonomy, participation, and control for the community'. Antlov developed the imagination of the village as an 'arena of democracy' long before the enactment of the Village Law. Most of Antlov's thoughts are actually embodied in several articles in the Village Law, especially those related to the issue of village community involvement (participation) in the process of democratization and village development.

One form of democracy in the village is the choice of the village head. Borrowing Antlov's term, that the village as an 'democratic arena' in the choice of the village head cannot be avoided from the practices of social exchange, as happened in the direct postconflict local election (governor's choice, regent's choice, mayor's choice). Several studies, as described below, legislative choices, direct head elections and village head elections cannot be separated from the practice of transactional politics or social exchange. The behavior of the village community as voters in the Village Head's choice, legislative choice, and direct post-conflict local election, is the 'vote holder' who can exchange with candidates/candidates.

Villagers even place any election moment as an opportunity to get money, basic necessities, promises, opportunities, or opportunities from the candidates. This kind of reality has led to the emergence of slogans from among the voters "Piro Wani Piro". Number (NPWP)", "there is money, there is support", "when will you get money from the candidate, not necessarily if you are in office you will give it". From the candidate, to win the election, the village head must prepare large amounts of money/costs. The strategies carried out include the "dawn attack" or "dhuha attack" before the vote is held. Social exchanges that occur between candidates and voters create dilemmas and debates. There are social exchanges in the form of money and goods which are interpreted as 'money politics', but there are also those who consider them as 'political costs'.

In reality, the implementation of the Village head's choice - such as the choice to the regions, the legislative choice, and the President's choice - cannot be avoided from money politics. Many experts state that money politics in direct elections is considered an injury to democracy. Various laws and regulations have been made to minimize the practice of money politics in the choice of the village head, but have not been able to eliminate it. Money politics is regulated in Article 149 of the Criminal 


\section{Social Exchange between Candidate Head of Village with Voters in Tuban Regency, East Java, Indonesia}

Code (KUHP). The penalty is nine months in prison or a fine of Rp. 500 million. If using the regulation on bribery, the threat is three years in prison and a fine of Rp. 15 million.

Social exchanges in the form of money and goods made by candidates to voters, are considered to be detrimental to democracy. However, from the community/voters perspective, this is considered 'natural'. If the candidate wants to get a lot of votes, he must prepare a large fee. "There is money, there is support. No money, no voice." In Blau's view, this kind of condition is called "the emergence principle" namely the existence of values and norms that are mutually agreed upon in the group. Shared social values serve as a medium for social transactions for organizations and social groups.

This kind of reality can give birth to an asymmetrical relationship between candidates and voters. There are two possibilities in this kind of asymmetrical relationship. The first possibility is that the candidate has a higher position than the electorate, because the candidate has financial resources as a means to influence voters. The second possibility is that voters are in a higher position than candidates, because voters have a 'vote' that can determine the candidate as village head.

Based on the description of the research background above, the problems that become the focus of this research are formulated as follows: (1) What is the type of social exchange that occurs between candidates and voters in the 2019 Sumberarum Village Head Election? (2) What elements form the social exchange between candidates and voters in the 2019 Sumberarum Village Head Election? (3) How did the candidate take advantage of the social exchange arena to win the 2019 Sumberaum Village Head Election? (4) What are the patterns of social exchange that occur between candidates and voters in the 2019 Sumberarum Village Head Election?

\section{LITERATURE REVIEW}

The asymmetrical relationship between candidates and voters can give birth to power in every form of exchange. For Homans, power relations are those subsets of social exchange relationships in which one person "gets less" from the exchange than another. Homans defines power broadly, thus including both positive and negative sanctions. So threats and punishments can be exchanged for rewards or for other threats and punishments.

Tjiptoherjanto \& Prijono (1983) have conducted research on village democracy in Java. Both of them examined the dominance of the village elite, which was oriented to the supra-village government. The domination of the village elite is a substantive sign of the decline of village democracy caused by social, economic changes and a shift in the leadership of the village head who is no longer the "father" of the people. Deliberation and mutual assistance, which were originally a form of village traditional democracy, turned into political practices characterized by various transactions or exchanges.

The current village head election system allows every citizen who meets the requirements to become a village head. The choice of the village head is a political activity and a democratic process that occurs at the village level and cannot be separated from the political dynamics in the village. Therefore, the choice of the village head is a tangible manifestation of political practice at the local level. Christensen (1995: 1) defines local politics as the process of decision-making, voting, and public policy carried out at the local (village) level. Local politics is characterized by when an individual or a small group of people can be directly involved and influence the decision-making and voting process.

In reality, the choice of the village head is not merely a struggle for position or power in the context of leadership succession in the village. The choice of the village head is also not merely a strategy match between candidates to gain voter support. More than that, the choice of the village head is a political means to fulfill the candidate's desire for power, prestige, self-respect and honor. To achieve this, various social exchange efforts were carried out by candidates to get as much support from voters as possible.

In this study, money politics that occurred in the choice of the 2019 Sumberarum Village head was not interpreted as something 'bad' or 'deviant', but rather seen as a 'cost' and 'profit'. Therefore, the theoretical perspective used to analyze this reality is social exchange theory.

The theory that is used as the theoretical basis in this research is the social exchange theory of Homanss, Blau and Emerson. The criticism of the three theorists is that they do not explicitly explain the types and patterns of social exchange. Therefore, this research is expected to offer the types and patterns of social exchange. Homans (1964) formulated the elements of social exchange including rewards and values of rewards, social rewards, costs, benefits, equality and distributive justice. Through this research, the researcher seeks to find and identify the elements of social exchange in the 2019 Sumberarum Village Head Choices.

Emerson was inspired by Homans and Blau's ideas. Emerson focused on the interactions and relationships between individuals and the parties involved in social exchange. Emerson's view emphasizes the availability of resources, power, and dependence as the main dynamics in social exchange. According to Emerson relationships are organized in different ways, and can differ depending on the type and amount of resources exchanged. Power and dependence are the main aspects that define a relationship. According to Emerson (1976: 335-362), Exchange is not a theory, but a framework from which other theories can 


\section{Social Exchange between Candidate Head of Village with Voters in Tuban Regency, East Java, Indonesia}

meet and be compared with structural functionalism. Emerson's perspective is similar to Blau's in that both focus on the relationship of power to the process of exchange. Emerson said that social exchange theory is an approach in sociology that is described for simplicity as an economic analysis of non-economic social situations. Exchange theory brings a form of quasieconomic analysis into the situation.

Most social exchange models share the same three basic assumptions: behavior in a social sense is based on exchange, if an individual allows someone to accept a gift, that person then feels the need to reciprocate due to social pressure and the individual will try to minimize their costs, while getting a return. maximum of the prize (Sprecher, 1998: 32 - 43). The assumptions of the existing Social Exchange Theory are tried to be proven through this research in the context of the 2019 Sumberarum Village Head Choice. These assumptions include: (1) There are three or more individuals who have the opportunity to exchange with each other. These actors are able to make decisions about whether to make the exchange, with whom to make the exchange, and under what conditions to make the exchange. (2) Social exchange produces positive to negative emotions. (3) Emotions can be interpreted as a reward or punishment, ie good feelings have a positive value and bad feelings have a negative value. (4) Individuals try to avoid negative emotions and to reproduce positive emotions in social exchanges. (5) Individuals will try to understand the source or cause of feelings generated by social exchange. In this way, the emotion is associated with the object that caused it. (6) Individuals interpret and exchange their feelings with respect to social relationships (eg partners, groups, networks). Positive emotions generated by the exchange will increase solidarity in the relationship, while negative emotions will decrease solidarity. Crossman (2020) identifies the basic assumptions of social exchange theory including: (1) People who engage in interactions rationally seek to maximize their profits. (2) Most of the satisfaction among humans comes from other people. (3) People have access to information about the social, economic, and psychological aspects of their interactions that enable them to consider alternative, more favorable situations compared to their current situation. (4) People are goal-oriented in a system of free competition. (5) Exchanges operate within cultural norms. (6) Social credit is preferred over social debt. (7) The more individuals feel deprived of an action, the more people will value it. (8) People are rational and calculate the best way to compete in favorable situations. The same is true for punishment avoidance situations.

Based on the explanation above, the theme of this research is social exchange in the 2019 Sumberarum Village Head Choice and the theoretical analysis knife is social exchange. The theory of social exchange was chosen because in reality the choice of the village head was suspected to have a thicker nuance of social exchange. This is due to the strong emotional connection between the candidate for village head and the community or voters. This emotional connection is built because of the proximity of the residence between the candidate and his voters, so that voters know very well the character, educational background, family background and public acceptance of the candidate.

The social changes that occurred in Sumberarum Village from an agrarian/traditional society to an industrial/modern society, made the Sumberarum Village community a transitional society. The dominance of the political dynasty leadership of the Singo Potro mbah breed which has lasted for a century has given rise to 'boredness' in some of the people of Sumberarum Village. The emergence of the notion of 'wis wayehe' (it's time) for leadership to change from the political dynasty of Ms. Singo Potro. The strong social exchange that occurred between the candidate and the community, and the candidate's victory led to the downfall of the Village political dynasty.

Social exchange theory and power analysis are two overlapping but distinguishable concepts. Integrating the analysis of social exchange theory and power conceptually can assist in selecting an overall social science research strategy. Dahrendorf (1958: 127) argues that at least two basic models of social science are necessary because "society has two faces of the same reality, the first being stability, harmony, and consensus and the second being change, conflict, and constraint." Similarly, Eckstein (1973: 161) argues that "there are two basic sciences of society: one that deals with symmetrical social relations and one that deals with asymmetry in socio-'economic' and 'political' units.' "There are two basic models of social interaction, which can combine cooperative and conflictual approaches.

Harsanyi (1969:515) states that modern game theory has demonstrated that "the same theoretical model can handle conflict and cooperation without any difficulty." The question here is whether social exchange theory can also be used to explain the two faces of social reality? Such an explanation has important implications for deciding how one stands on the question posed by Eckstein and Dahrendorf.

Curry \& Wade (1968: 118) have noted that critics of the social exchange model often claim that power "cannot be understood in terms of exchange by definition because no exchange occurs in a power relationship-there are only 'winners' (in power) and 'losers'. ' (the powerless) and no bidirectional distribution of rewards and costs." The question of whether and how social exchange models can be used to improve understanding of power has no generally agreed answer. It can be said that: (1) all exchange relations can be explained in terms of the conventional concept of power without distorting the common sense understanding that underlies the concept; (2) most-but not necessarily all power relations can be described in terms of social exchange; (3) there 


\section{Social Exchange between Candidate Head of Village with Voters in Tuban Regency, East Java, Indonesia}

are several advantages to imagining power in this way; (4) recent social exchange theorists do not explain or acknowledge most of these advantages.

\section{RESEARCH METHODS}

\section{Research paradigm}

This study uses the social definition paradigm. This paradigm prioritizes the process and meaning of individuals who take action. The social definition paradigm is a perspective that focuses on how individuals understand (verstehen) so that they act or take actions on the basis of the meanings they have and benefit themselves. The action was in the form of a social exchange phenomenon of voters in the 2019 Sumberarum Village Head Election in Sumberarum Village. To reveal this social reality, the researchers tried to explore and look for the meaning of the community towards the wishes and actions in the context of the use of social networks by prospective village heads, the system and social status of leadership and the use of traditional media in the Election of the Village Head of Sumberarum.

\section{Research Approach}

This research approach is a qualitative approach. Qualitative research is research that tends to use analysis based on the perspective of research subjects. The qualitative approach is applied to natural conditions and is inventive in nature. In a qualitative approach, the researcher acts as well as the research instrument. In this case, researchers are required to have a broad theory and insight as a basis for asking questions, analyzing and constructing the object under study.

The essence of qualitative research is observing people in their social situations, trying to understand language and interpreting the world around them, researchers trying to interact with people related to the research focus. Through a qualitative approach, the researcher seeks to understand, explore the views and experiences of research subjects related to the focus of this research. The qualitative approach is directed at the social background and social interaction as a whole. Consequently, the qualitative approach produces descriptive data in the form of written words or oral answers from the people observed.

A qualitative approach is used to describe a series of events related to the experiences of the residents of Sumberarum Village in the 2019 Village Head Election. The event in question is the social exchange of voters in the 2019 Sumberarum Village Head Election. With this approach the process and meaning of social reality are interpreted from the point of view of the research subjects. The basis of the theory of social exchange and the theory of political dynasties is used as an 'analysis knife' of the reality under study.

\section{Types of research}

This type of research is a case study. Case study research focuses on a particular case in depth so as to identify social relationships, processes and categories that are simultaneously recognizable, distinctive, and unique. Case studies require sufficient detail to provide an overview of a case. Case studies are usually specific, but that doesn't mean they can't be applied to broader social processes. Case study research consists of a detailed investigation, often data collected over a period of time, of a particular phenomenon and context whose purpose is to provide an analysis of the context and processes related to the theoretical issue being studied. This phenomenon cannot be separated from its context, but becomes interesting when the goal is to understand the behavior that is influenced by certain content.

In order to find the hidden life principles of the Sumberarum Village community, researchers must be 'students' while the candidate for village head in the 2019 Sumberarum Village Head Election, voters, youth leaders, religious leaders and community leaders are the 'teachers'. This position requires researchers to 'learn' more about their lives to be described as case study notes and reports.

The community of Sumberarum Village is seen as having a unique system in perceiving and organizing material phenomena such as objects, events, behaviors, and emotions that take place and are related to the 2019 Sumberarum Village head's choice and the collapse of the political dynasty in Sumberarum Village. The object of this case study is not the material phenomena, but the way in which these material phenomena are organized in the human mind. In simple terms, the habits or culture of the people of Sumberarum Village are seen as being in the human mind and its form is the organization of thoughts about material phenomena. The task of the case study is to find and describe the organization of the mind. Then, the right way to acquire cultural knowledge stored in the mind is through language.

Stake (2005) calls the case a closed system, the case is formed from many elements, parts, components, or units that are interrelated and form a certain function. To be able to reveal why and how these parts, components, or units are related to each other in forming a function, an appropriate method is needed. The method must be able to dig up facts from various data sources, analyze and interpret them to raise the basic substance behind the case under study. The research method is a case study research method. 


\section{Social Exchange between Candidate Head of Village with Voters in Tuban Regency, East Java, Indonesia}

Data collection methods used include observation, interviews, collecting life stories or other strategies, language will always appear at every phase in the research process. Case studies have two main tasks, namely discovery and description, in this case language plays an important role.

\section{Research Locus}

The focus of this research includes social exchanges in the 2019 Sumberarum Village Head Election. The location of this research is in Sumberarum Village, Kerek District, Tuban Regency. Sumberarum Village, is one of the villages in Kerek District which is close to the Semen Gresik factory area of the Tuban factory. Sumberarum Village is divided into three hamlets, namely Sumberarum Hamlet, Sumberjo Hamlet, and Sumbermakmur. The village government center is in Sumberarum Hamlet.

\section{DISCUSSION AND RESULTS}

Direct social exchange is a social exchange that is carried out between candidates and voters directly, using both extrinsic and intrinsic rewards. People who have direct social exchanges with candidates are called "botohs". The existence of "botoh" for candidates is considered like a success team, because "botoh" must choose the candidate they support. The candidate's relationship with "botoh" can be formed because there is close kinship, relatives, friends or neighbors.

Based on the answers of the research subjects mentioned above, that social exchange does not always use money/materials. Social exchanges between candidates and voters, more specifically botoh, are due to several things, including emotional closeness, kin/relative relationships, and reciprocation. This kind of relationship is a form of reciprocal type of exchange, namely a reciprocal relationship. A give-and-take relationship. The norm in this kind of relationship is "kindness is rewarded with kindness". However, this kind of relationship does not apply, if one of the parties feels that they do not benefit positively from the relationship. Relationships that are felt to be of no benefit or advantage can lead to disappointment. Therefore, social exchange in this context can be of negative or positive type.

\section{Social exchange actor}

The social exchange actors referred to in this case are candidates (sequence numbers 1 and 2 ) and voters, in this case the residents of Sumberarum Village who have the right to vote. There were 987 male voters and 1052 female voters, with a total of 2039 voters. The two candidates are competing for the 2039 votes. In this study, not all voters were studied. Only some of the voters who are determined as research subjects are studied. In the social structure, the two candidates are the political elite and the economic elite, while the voters are villagers who only have a 'vote' in the choice of the village head. Candidates as political elites, because they have the ability to influence other people/ villagers/ voters. Both influence to choose himself and not choose his opponent. Called the economic elite, because the candidate is a person who has economic resources in the form of money or wealth that can be used as capital in fighting for the seat of the village head. According to the confession of the two candidates, each prepared a capital of 1.5 billion rupiah (candidate number 1 ) and 500 million (candidate number 2). This capital is part of the extrinsic sacrifice prepared by the candidate in fighting for the position of the village head of Sumberarum. The relationship between social exchange actors in the 2019 Sumberarum Village Head Choice can be horizontal and vertical.

\section{Patterns of Social Exchange}

The pattern of symmetrical exchange between candidates and voters occurs when the position between the two is equally in need. No one dominates or dominates. Candidates need support from voters and voters need money, basic necessities, and hopes from voters. This kind of exchange relationship is further strengthened by the fact that both of them are from the same village. This exchange relationship can be found at the time of champion between candidates and voters.

Homans and Blau both recognize the existence of power in a social exchange. Blau (1964: 115-142) recognizes the existence of two concepts of power in exchange. The first concept, has a broad enough meaning to include exchange, and the second concept has a narrow enough meaning to exclude it. Power in a broad sense refers to any type of influence between people or groups, including that exercised in exchange transactions, where one person persuades another to agree to his or her wishes by rewarding them for doing so. Power in a narrow sense that completely overrides positive sanctions. Thus, instead of synthesizing the concepts of exchange and power, Blau emphasizes the split between the two concepts.

For Homans, power relations are those subsets of social exchange relationships in which one person "gets less" from the exchange than the other. Homans defines power broadly, thus including both positive and negative sanctions. So threats and punishments can be exchanged for rewards or for other threats and punishments. Homans (1974: 79-81) analyzes the "money or your life" situation as an exchange and draws out the similarities and differences between coercive and non-coercive exchanges. Although there are weaknesses in Homanss' concept of power, his broad concept of power and his attempt to integrate the concepts of power and social exchange are steps towards synthesis. 


\section{Social Exchange between Candidate Head of Village with Voters in Tuban Regency, East Java, Indonesia}

The existence of power in social exchange, can lead to asymmetric interaction patterns. This asymmetric pattern occurs because of several things: (1) one party gets less than the other party; (2) either party may impose its will on the other party; (3) the source of power exchanged can be in the form of extrinsic and intrinsic rewards; (4) each party does not understand the purpose of social exchange, and (5) asymmetrical relationships can take place dynamically. In the context of the election of the village head, the candidate may occupy a higher position than the voting community. This is because the candidate has resources in the form of the ability to influence others and financial resources. On the other hand, the voting community can also be in a higher position, when the 'vote' owned by the voting community is much more meaningful and more expensive than the candidate's money.

\section{v. CONCLUSION}

The elements of social exchange between candidates and voters in the 2019 Sumberarum Village Head Election include: social exchange actors (candidates and voters), goal-oriented behavior, rewards (extrinsic and intrinsic), costs, and social exchange norms. These five elements are prerequisites for social exchange.

The arena used by candidates in conducting social exchanges with voters is a tradition that applies in Sumberarum Village in the context of the Village head election. These traditions include mlawang, jagong, mayoran and delivery. This tradition is used by candidates to ask for blessings as well as support in the 2019 Sumberarum Village head election. Through this tradition, candidates can exchange material and non-material things with voters. The materials that became the means of exchange were money and basic necessities. The non-materials that are the means of exchange are promises and kindness/reciprocation.

The pattern of social exchange in the choice of the village head of Sumberarum is a pattern of symmetrical and asymmetrical social exchange. Several notions of power as inherently asymmetric have been examined. The notion of causal asymmetry is valid but can be confusing when applied to power relations. However, the notions of "unbalance" and "unequal benefits" have serious drawbacks. The concept of power in social exchange between candidates and voters can involve symmetrical and asymmetric power relations. Because the exchange relationship connotes reciprocity and possibility - but not necessity - symmetry, the notions of "unequal" and "unequal benefits" of power as inherently asymmetric are not suitable for inclusion in the exchange model.

\section{REFERENCES}

1) Amanulloh, N. (2015). Demokratisasi Desa. Jakarta: Kementerian Desa, Pembangunan Daerah Tertinggal, dan Transmigrasi Republik Indonesia.

2) Blau, P.M. (1964) Exchange and Power in Social Life. New York: John Wiley \& Sons. Inc. Christensen, T. (1995). Local Politics: Governing at The Grassroots. California: Wadsworth Publishing Company.

3) Curry, R.L., \& Wade, L.L (1968). A Theory of Political Exchange: Economic Reasoning in Political Analysis. Englewood Cliffs, N.J.: Prentice-Hall.

4) Dahl, R.A. (1976). Modern Political Analysis, 3rd ed. Englewood Cliffs, N.J.: Prentice-Hall.

5) Dahl, R.A. \& Lindblom, C.E. (1953). Politics, Economics, and Welfare. New York: Harper and Row.

6) Deutsch, Karl W. (1963). The Nerves of Government. New York: Free Press.

7) Geertz, C. (2017). Agama Jawa: Abangan, Santri, Priyayi dalam Kebudayaan Jawa. Depok: Komunitas Bambu.

8) Harsanyi, J.C. (1962). "Measurement of Social Power, Opportunity Costs, and the Theory of Two-person Bargaining Games."

9) Homans, G.C. (1964). Social Behavior: Its Elementary Forms, rev. ed. New York: Harcourt, Brace, Jovanovich.

10) Huda, N. (2015) Hukum Pemerintahan Desa. Malang: Setara Press.

11) International IDEA Handbook Series 4. (2001). Democracy At The Local Level. The International IDEA Handbook on Participation, Representation, Conflict, Management, and Governance. International IDEA Handbook Series 4. Strömsborg, SE 103 34. 2001.

12) Kartohadikoesomo, S. (1984). Desa. Jakarta: PT Balai Pustaka.

13) Lasswell, H.D., \& Kaplan, A (1950). Power and Society. New Haven: Yale University Press.

14) Parsons, T \& Smelser, N.J (1956). Economy and Society: A Study of the Integration of Economic and Social Theory. Glencoe, III.: Free Press.

15) Raho, B. (2007). Teori Sosiologi Modern. Jakarta : Prestasi Pustaka.

16) Ritzer, G. (2014). Teori Sosiologi Modern. Edisike-7. Jakarta : Kencana.

17) Schelling, T.C. (1960). The Strategy of Conflict. Cambridge, Mass.: Harvard University.

18) Simon, H.A. (1957). Models of Man. New York: Wiley.

19) Soemantri, B.T. (2011) Pedoman Penyelenggaraan Pemerintahan Desa. Bandung: Fokusmedia. 


\section{Social Exchange between Candidate Head of Village with Voters in Tuban Regency, East Java, Indonesia}

20) Stake, R.E (2005) The Art of case study research. California: Sage Publications, Thousand Oaks.

21) Tjiptoherijanto, P. \& Prijono, Y.M. (2012). Demokrasi di Pedesaan Jawa. Jakarta: Penerbit Kosa Kata Kota.

22) Waldman, S.R. (1972). Foundations of Political Action: An Exchange Theory of Politics. Boston: Little, Brown.

23) Weber, M. (1947). The Theory of Social and Economic Organization. Translated by A. M. Henderson \& Talcott Parsons; edited by Talcott Parsons. New York: Free Press.

24) White, R.K. (1970). Nobody Wanted War: Misperception in Vietnam and Other Wars. Garden City, N.Y.: Doubleday.

25) Widjaja, HAW. (2008). Otonomi Desa merupakan Otonomi yang Asli, Bulat dan Utuh. Jakarta: PT.RajaGrafindo Persada.

26) Zeitlin, I. (1995). Memahami Kembali Sosiologi. Yogyakarta : UGM Press

\section{Scientific Journals}

1) Alamsyah. "Dinamika Politik Pilihan kepala Desa di Era Otonomi Daerah: Studi tentang Relasi Politik Calon Kepala Desa dengan Para Pemilih Pilihan kepala Desa". Jurnal TAMANPRAJA Vol. 1, Edisi 1, Juni 2011 (ISSN: 2087-9598)

2) Amanu, M. "Politik Uang dalam Pemilihan Kepala Desa (Studi Kasus di Desa Jatirejo Kecamatan Banyakan Kabupaten Kediri)." Jurnal Mahasiswa Sosiologi. Vol. 1, No, 2 (2015)

3) Antlöv, H. (2003). "Kerangka Hukum Pemerintahan Desa Menurut UU No. 22 Tahun 1999", Jurnal Forum Inovasi, MaretMei 2003.

4) Antlöv, H., Wetterberg, A., \& Dharmawan, L. (2016). "Village governance, community life, and the 2014 village law in Indonesia", Bulletin of Indonesian Economic Studies, Vol.52(2), pp. 161-183.

5) Asrorudin, M.H \& Fauzi, A.M. "Pertukaran Sosial Elit Pendukung dan Pasangan Calon Pada Pilihan kepada daerah: Studi Kasus Kemenangan SYAHTO Pada Pilihan kepada daerah Tulungagung 2018". Jurnal PARADIGMA. Vol. 9. No. 1 (2020)

6) Awortwi, N. "An unbreakable path? A comparative study of decentralization and local government development trajectories in Ghana and Uganda", International Review of Administrative Sciences 77: 347. (2011)

7) Baldwin, D.A. "Money and Power." Journal of Politics 33:578-614. (1971a).

8) Boulding, K.E. "Towards a Pure Theory of Threat Systems." American Economic Review 53:424-34. (1963).

9) Clarke, S.E. "Local Politics in a Global Era: Thinking Locally, Acting Globally". The Annals of the American Academy of Political and Social Science 551(1):28-43 (1997) DOI:10.1177/000271629755100103

10) Crossman, A. (2020) Understanding Social Exchange Theory. Social Science. https://www.thoughtco.com/socialexchange-theory-3026634

11) Dahrendorf, R. "Out of Utopia: Toward a Reorientation of Sociological Analysis." The American Journal of Sociology 64:115 -27. (1958).

12) Dahl, R.A. (1957). "The Concept of Power." Behavioral Science 2:201-15.

13) Dahl, R.A (1968). "Power." In International Encyclopedia of the Social Sciences, Vol. 12. New York: Free Press, pp. 405-15.

14) Eckstein, H. "Authority Patterns: A Structural Basis for Political Inquiry." American Political Science Review 67:1142-61. (1973).

15) Emerson, R M (1976). "Social Exchange Theory". Annual Review of Sociology. 2: 335-362. doi:10.1146/annurev.so.02.080176.002003

16) Gyford, J. "Diversity, sectionalism and local democracy." Widdicombe Report. The Conduct of local authority business, Research Vol. 4, Cmnd 9801 (june). London: HMSO.

17) Haliim, W. "Perspektif Pertukaran Sosial dalam Perilaku Politik Masyarakat pada Pilihan kepada daerah Kota Malang 2013." Politik Indonesia: Indonesia Political Science Review. Vol 2, No 2 (2017).

18) Halili. "Praktik Politik Uang dalam Pemilihan Kepala Desa (Studi di Desa Pakandangan Barat BlutoSumenep Madura). Jurnal Humaniora. Vol 14. No 2 Oktober 2009. Hal. $99-112$.

19) Liata, N. "Relasi Pertukaran Sosial antara Masyarakat dan Partai Politik". Jurnal Sosiologi Agama Indonesia (JSAI), 1(1), 79-95 (2020)

20) March, J.G. "An Introduction to the Theory and Measurement of Influence." American Political Science Review 49:431451. (1955).

21) Nagel, J.H. "Some Questions About the Concept of Power." Behavioral Science 13:129-37. (1968).

22) Nuruddin, M. “Penggunaan Teori Pertukaran Sosial Peter M. Blau dalam Menganalisis Pilihan kepala Desa (Studi Kasus di Desa Karangbener)". Jurnal Addin. Vol 3, No 1 (2011).

23) Parsons, T. (1963). "On the Concept of Political Power." Proceedings of the American Philosophical Society 107:232-62.

24) Rohmawati, T. "Dinamika Politik Pedesaan dalam Pemilihan Kepala Desa Masin Kabupaten Batang Provinsi Jawa Tengah". Program Studi IImu Pemerintahan, Fakultas IImu Sosial dan IImu Politik Unikom Universitas Komputer Indonesia. 2018 


\section{Social Exchange between Candidate Head of Village with Voters in Tuban Regency, East Java, Indonesia}

25) Saefulrahman, I. "Kepemimpinan, Modal Sosial dan Pembangunan Desa (Kasus Keberhasilan Pembangunan di Desa Pangauban Kecamatan Cisurupan Kabupaten Garut)." CosmoGov, Jurnal Ilmu Pemerintahan. Vol.1 No.1, April 2015. ISSN 2442-5958

26) Sari, D.P, Fitriyah, \& Kushandayani. "Perilaku Pemilih dalam Pemilihan Kepala Desa (Pilihan kepala Desa) Desa Mranak Kecamatan Wonosalam Kabupaten Demak Tahun 2016," Journal of Politic and Government Studies, Vol. 7, no. 1, pp. 8190, Dec. 2017. [Online].

27) Sprecher, S., (1998). Social exchange theories and sexuality. Journal of Sex Research, 35(1), 32-43.

28) Wrong, D.H. "Some Problems in Defining Social Power." American Journal of Sociology 73:673-81. (1968)

29) Yuningsih, N.Y. \& Subekti, V.S. “Demokrasi dalam Pemilihan Kepala Desa? Studi Kasus Desa Dengan Tipologi Tradisional, Transisional, dan Modern di Provinsi Jawa Barat Tahun 2008-2013”. Jurnal Politik. Vol. 1. No. 2. Februari 2016. 